\title{
De minimis non curat lex: A Profound Juridical Unity?
}

\author{
EDWARD MORGAN ${ }^{1}$ \\ Barrister
}

In recent years, those involved in regulating, forming or advising faith communities have had much to contend with: the expansion of the vicarious liability doctrine, the status of ministers of religion and the decision in Shergill v Khaira, not to mention the General Data Protection Regulation. These issues share a common denominator: they require faith communities to give close consideration to the values which they seek to articulate and foster in the expression of their own autonomy and right of self-determination. That is, they serve as a prompt to reconnect with the intellectus and vinculo iuris of their own ecclesial norms. This article is intended to encourage such an exercise and to contribute to a discussion of the potential points of collaboration between the civil law and faith communities in securing dispute resolution by which ecclesial values may be accommodated.

Keywords: religious freedom, de minimis, jurisprudence

\section{INTELLECTUS AND VINCULO IURIS?}

The purpose of this article is primarily to share ideas. This is not because conclusions are not possible, but because 'law' is a dynamic subject and the manner and form in which it finds expression is heavily fact-sensitive. However, for all jurists (practitioners, commentators and judges) there comes a time when one is required to engage with the 'why' question (for example, why does the law recognise certain promises and not others as being legally enforceable?). It is, I suggest, only through the 'why' question that we come to engage with the intellectus of the legal system itself: its origins, its cultural influences and, perhaps more familiar to secular jurists, the underlying sociopolitical ideologies to which the law seeks to give effect. ${ }^{2}$ These same factors, influencing as they do the formulation and adaptation of the juridic environment, also provide the primary indices of the vinculo iuris (that is, the basis upon which the law lays claim to our obedience or seeks to secure our adherence).

1 This article is the text of the John Lewis Memorial Lecture given at Cardiff University on 28 April 2018. The text has also been published in the Newsletter of the Canon Law Society of Great Britain and Ireland. The term 'profound juridical unity' is taken from N Doe, Christian Law: contemporary principles (Cambridge, 2103), p 186. The maxim De minimis non curat lex is usually translated 'the law does not concern itself with trifles'.

2 One need only think of the revision of the doctrine of 'vicarious liability' in recent years, as an illustration of policy-driven principle. 
It is sometimes suggested that legal systems invoke one of three foundational principles in support of autonomy and legal competence: religious belief (theocracy), monarchical sovereignty (the divine right of kings) or political mandate (social contract theory). In historical terms, the common law tradition has experienced all three. ${ }^{3}$ Along the way, the interrelationship between law and religion has not been entirely consistent. Common law constitutional history is nonetheless peppered with documents which have shaped - if not determined - the communal understanding of law and secured legal accountability. ${ }^{4}$ From these documents one is able to discern a reception of law as the safeguard of both the individual and communal interest, while also serving as a means of restraint against the arbitrary use of power or illegitimate conduct on the part of those exercising political authority. ${ }^{5}$

Since the 1970s, the protectionist dimension of late eighteenth-century legislation has been supplemented by educative measures to rid society of conduct considered harmful to individuals and the values of social pluralism. ${ }^{6}$ Still more recently, there has been a dramatic increase in domestic and community legislation drawing upon a secular (that is, non-religious) perspective of the human condition, promulgated as part of a teleological scheme. In each instance, legislation has declared 'rights', 'liberties' and 'freedoms' said to be

3 For an excellent and highly readable account of the transformation of the absolute monarchy in England, see $\mathrm{R}$ van Caenegem, An Historical Introduction to Western Constitutional Law (Cambridge, 1995), pp 109 ff: 'More and more people, in parliament and elsewhere, came to believe that the King eroded the ancient Constitution and the common law might fail to protect their persons against the incursions of the absolute prerogative' ( $p$ 111) and 'The Stuart era resulted in constitutional limits being imposed on the monarchy, and supreme power passing into the hands of parliament; thus the celebrated model of constitutional and parliamentary government ... took shape'. It is important to record that the theory of wider political mandate became a feature of British Constitutional theory as late as the nineteenth century, with the emancipation of various classes of person previously denied any political mandate (for example the Catholic Relief Act 1829) said to have been prompted by the election of a Catholic (O'Connell) as Member of Parliament for Clare, who would otherwise have been unable to take up a seat in the House of Commons. As Berman has noted, the historiography of England conceived of these political changes and shifts in constitutional thought as 'restorations of ancient liberties of Englishman as laid down in Magna Carta'. See H Berman, Law and Revolution Vol II: the impact of the Protestant reformations on the Western legal tradition (Cambridge, MA, 2003), p 26.

See, for instance, Magna Carta (1215), the Petition of Right (1628), the Act of Habeas Corpus (1679) and the Bill of Rights (1689).

5 The anniversary of Magna Carta has prompted a good deal of reconsideration of its constitutional importance. The commentary by David Carpenter - D Carpenter, Magna Carta (London, 2015) has entered a third edition. See also A Arlidge and I Judge, Magna Carta Uncovered (Farnham, 2014), p 25: 'Although the Charter of 1215 was expressed to bind the King's successors, later generations up to the fourteenth century insisted on its confirmation'; R Griffith-Jones and M Hill (eds) Magna Carta, Religion and the Rule of Law (Cambridge, 2015), p 27, on the various iterations of the Charter: 'It remained a deal: your taxes, our rights'. Each discussion has sought to elicit from the Great Charter a renewed understanding of its historical and present-day significance. The latter aspect is considered below in relation to the common law understanding of 'rights'.

6 A good deal of this legislation emanates from EC Directives as a result of membership in the European Union. See the European Communities Act 1972. As to the international sources of rights in English law, see Halsbury's Laws of England, vol 88A (fifth edition, London, 2003), pp 89 ff. 
inherent to received notions of social inclusion and equality. In juridic terms at least, the result points to a society under construction asserting values yet to be attained. In consequence, the resultant legal method is one in which laws are promulgated and applied as a juridic contribution to creating, preserving or advancing a societal vision and order. As the saying goes: ubi societas, ubi ius ('wherever there is society, there is law'). However, I would suggest that this translation of ideological ambition is reducible to a triptych:

$$
\text { value } \rightarrow \text { norm } \rightarrow \text { purpose }
$$

For this purpose, 'value' represents the philosophical, doctrinal or theological ambition or ambitions to which the community subscribes. The norm is intended to serve as the juridic formulation of that same value, whereas the purpose is the intended consequence to which the legal norm (or the legal system of which it is part) is directed. The scrutiny of communal laws and/or societal rules in this way provides very real benefits. This is particularly so where the legal norms in question are said to represent the juridic articulation of theological or doctrinal values to which a particular faith community subscribes. The significance of this, given recent judicial pronouncements, is addressed below.

Within this same environment, it is the primary function of private law (whether in the form of legislation, judicial pronouncement or the recognition of custom) to affirm the legal consequences of relationships through the recognition of interpersonal and communal obligations. A cursory examination of the history of the common law confirms this to be the case. ${ }^{7}$ More recently, our legal system has confirmed its subscription to fundamental freedoms. ${ }^{8}$ These same freedoms are said to cloak the person with certain entitlements inherent to the human condition, with limitation being permissible only where certain preconditions are met and where it is necessary in a 'democratic society' to achieve one or more permitted purposes. ${ }^{9}$ While the express religious content of the law has been largely removed, the systemic alignment with a philosophical or ideological value remains, notwithstanding the fact that many commentators would rail at the use of such terms. Thus, the common law offers a socio-juridical environment in which law as the articulation of value is afforded precedence; this is consonant with an anthropocentric perspective of law as serving the human condition.

7 A detailed survey of this change is provided by T Plucknett, A Concise History of the Common Law (fifth edition, London, 1956).

8 See Human Rights Act 1998.

9 See, by way of example, the text of Art 9(2) ECHR: 'Freedom to manifest one's religion or beliefs shall be subject only to such limitations as are prescribed by law and are necessary in a democratic society in the interests of public safety, for the protection of public order, health or morals, or for the protection of the rights and freedoms of others.' 
Within the experience of the common law and the conceptual constructs upon which it relies (such as promises, assurances or assumption of duty), there is evidence of a commitment to an underlying philosophical system in which the integrity of personal and hierarchical interaction enjoys a central position.

\section{PRACTICAL RELEVANCE?}

Oliver Wendell Holmes once observed: 'The law is the witness and external deposit of our moral life ... The practice of it, in spite of popular jests, tends to make good citizens'. ${ }^{10}$ This is more than rhetoric. It might be said that Wendell Holmes was paraphrasing the Aristotelian understanding of law as the means by which members of society may be encouraged to act for their own personal virtue: in short, a perception of law and laws as serving an educative function in the formulation of both individual and communal conscience. What has this to do with the role of canonists and advisors to faith communities? In attempting to answer this question, it is important to keep in mind the following:

i. Many religions incorporate, accommodate or are to some degree dependent upon the formulation and adoption of human associations;

ii. This may be inherent to forms of religious expression and/or the transmission of belief (for example, collective worship, declarations of shared belief, or shared living);

iii. Such associations provide an environment in which the formulation, development and practice of belief may be expressed and protected;

iv. Those faith communities not enjoying establishment status will invariably utilise structures recognised by the secular law in order to acquire juridic recognition, competence or contractual capacity;

v. From the perspective of the faith community and the demands of the secular law, both the faith community and the individual members will commonly be regulated by 'rules' or principles of conduct which the faith community has promulgated; and

vi. It is thus inevitable that both faith community and believer will to some degree be participants in a relationship of membership which is potentially susceptible to conflicting perspectives, namely: that required by the secular law and that which may be gleaned from the ecclesiological or doctrinal understanding of the faith community itself.

Few members, believers or participants are likely to view their participation within the faith community as founded upon a legal contract. Nonetheless, 
the dynamic of communal participation - while intended to confer eligibility, inclusion and participation - is equally concerned with issues of licence, permission and regulation. Insofar as faith communities provide for the conferral of office, the imposition or assumption of duties and/or the recognition of rights, they invariably do so with an ecclesiological, or at least doctrinal, understanding of those offices, the responsibilities of the office-holder and the character of their participation in a community of belief. This understanding will in turn be tied up with issues of doctrine and mission.

The judicial analysis of the so-called clergy employment cases is outside the scope of this article. It is to be noted, however, that the courts have travelled some distance in their willingness to uphold contractual relations generated in such circumstances. However, the existence of a contractual relation (whether classified as one of employment or not) and the terms of the resultant contract are two very different matters. It is in this area that recent case law may be considered to serve as a prompt to faith communities to ensure that their own internal values, mission and purpose are not lost in translation. It may be said that this is a consequence of the fact that society and religion are conceptually opposed. Equally, one might conclude that the difficulty which arises here is the product of legal pluralism (that is, the fact that religious laws will often require compliance in multiple environments which are the subject of secular laws).

However, legal pluralism is not a new experience. Nor does it automatically result in the relegation of religious principle. This may best be shown by two short illustrations.

\section{Judaism}

Within scripture, the Judaic tradition is presented as a faith community in receipt of law as a gift from God, albeit a community which is in exile, seeking to articulate and maintain its own religious, cultural and moral identity in a legally pluralistic environment. The demands of the covenant (mitzvoth) represent the currency of the relationship between God and His people: berit. ${ }^{11}$ In short, this is a sociopolitical model in which laws articulated retain a sacred duty and component. It is apparent from the various narratives that law did not comprise a single category of rules, requiring uniformity of application or response. While certain rules were perceived as sacred, others touched upon matters of morality. Still further rules were concerned with private transactions. Non-compliance with these various categories called for different forms

11 D Novak, 'Law and religion in Judaism' in J Witte and F Alexander (eds), Christianity and Law: an introduction (Cambridge, 2008), pp 35-36. While the term berit is often translated in the form of covenant, it is more consistent with the provision of a unilateral unsolicited promise. By this means, the mitzvoth represents the voluntarily bestowed gift of God to guide His people to life, a life which accords with human dignity and the human's relationship with God, their creator. 
of judicial response, ranging from punishment through retaliation to compensation. More fundamentally, the casuistic formulation of legal rules left little room for the suggestion that these 'laws' were anything other than normative and mandatory, a position underscored by the protasis-apodosis technique (for example, if a man commits adultery with the wife of his neighbour, both the adulterer and the adulteress shall be put to death). ${ }^{12}$

A number of observations may be drawn from this reality. First, the Jewish tradition affords recognition to normative rules and customs which require compliance for the benefit of both individual and community. Second, nonadherence to these same norms has a direct bearing upon the relationship with the divine - a God with whom the faith community (collectively and individually) shared a covenant. Third, the Judaic community was/is uninterested in the formulation of social norms for the sake of communal order and stability alone. The community would not regard itself as a mere aggregation of persons or simply sharing a coincidence of common interests. Rather, the social unit comprised the product of divine election. The result is a worldview in which the lived experience necessarily requires reconciliation with the destiny to which the 'Chosen People' are directed. ${ }^{13}$ This is some distance away from a mere 'association' of a secular kind.

\section{Catholicism}

According to Cicognani, the Church was a party to a form of toleration or symbiotic relationship with the secular power following the Edict of Milan. ${ }^{14}$ But what of the Church's view of law generally? Two major influences are at work here: Augustine of Hippo and Thomas Aquinas. Augustine concluded that the celestial and earthly cities were fundamentally irreconcilable. Social communities were, for him, nothing more than an artificial construct (societas) ${ }^{15}$ where

12 Leviticus 20:10 ff.

13 The terminology of this legal culture was inextricably linked with this theological understanding, an understanding which defined both person and community. As has been observed, the Judaic term for obligation (mitzvah) is 'bound up in a myth - the myth of Sinai. Just as the myth of the social contract is essentially a myth of autonomy, so the myth of Sinai is essentially a myth of heteronomy. Sinai is a collective - indeed a corporate - experience. The experience of Sinai is not chosen ... All law was given at Sinai and therefore all law is related back to the ultimate heteronomous event in which we are chosen - passive voice.' And 'Indeed, to be the one who acts out of obligation is the closest thing to a Jewish definition of completeness as a person within the community.' See R Cover, 'A Jewish jurisprudence of the social order', in M Walzer (ed), Law, Politics, and Morality in Judaism (Princeton, NJ, 2006), pp 3-11 at pp 4 and 5 .

14 A Cicognani, Canon Law (second edition, Baltimore, MD, 1934), pp 49-51.

15 Augustine, City of God, Book XIV, 28: 'Accordingly, the two cities have been formed by two loves: the earthly city by the love of self, even to contempt of God; the heavenly city by the love of God even to the contempt of self. The former, in a word, glories in itself, the latter in the Lord ... In the [heavenly] city there is no human wisdom but only Godliness, which offers due worship to the one God.' This translation is that adopted in P Schaff (ed), St Augustin's City of God and Christian Doctrine (Buffalo, NY, 1887). 
allegiance was formed for the purpose of enforcing man-made laws. ${ }^{16}$ For Augustine, such 'laws' were primarily a counter to 'violence'. One is thus left with an Augustinian view of law as a necessary ingredient to social harmony, identified and imposed not because the norm is virtuous per se or consistent with the attainment of virtue, but rather as a means of attaining an inferior form of peace, through coercion. ${ }^{17}$ In short, this is a regime of regulation akin to that enjoyed by the paterfamilias of Roman law. ${ }^{18}$ One will look in vain for any concession as to the educative qualities of human law. ${ }^{19}$

The Augustinian and Thomist perspectives could not have been more disparate. For Aquinas, law was the ordinance of reason directed to the common good. ${ }^{20}$ Constituent laws were both normative and directive: normative in that the law defined the conduct required (or prohibited) and directive by reason of the fact that the laws anticipated and required compliance. The coercion inherent to law was not, however, the deterrent of punishment, but the rational imperative seeking the restoration of reason, and thus order. ${ }^{21}$ In this way, law

16 Augustine viewed this somewhat disparagingly: see City of God, Book XV, 8. Having adverted to the story of Enoch, he writes: 'for at that time, he, being a solitary man, could not have founded a civic community, which is nothing else other than a multitude of men bound together by some associating tie.' It is helpful to read this passage alongside an extract from his Confessions, Book III, 8(15): 'Transgressions against human codes are a different matter: they vary in accordance with variable customs; but they are to be avoided all the same, lest an agreement made between citizens or compatriots among themselves, and rendered stable by custom and law, be violated at the whim of a citizen or a foreigner ... If, on the other hand, God commands something which conflicts with the custom or rules of any human society, then it is to be done' (Augustine, The Confessions, trans M Boulding, ed J Rotelle (London, 1997), p 86). A markedly different translation is provided in the Hendrickson edition, which refers not to human codes but to 'customary morality': Augustine, The Confessions, ed A Outler (Peabody, MA, 2004), p 47.

17 Augustine, City of God, Book XIX, 17: 'The earthly city, which does not live by faith, seeks an earthly peace, and the end it proposes, in the well ordered concord of civil obedience or rule, is the combination of men's wills to attain the things which are helpful to this life. The heavenly city, or rather that of it which sojourns on earth and lives by faith, makes use of this peace only because it must'.

18 Ibid, Book XXII, 22: 'the human race is restrained by law and instruction, which keep guard against the ignorance that besets us, and oppose the assaults of vice, but are themselves full of sorrow ... From this hell on earth there is no escape save through the saviour Christ, our God and Lord.'

19 Righteousness was thus only available through the law of God. See Augustine, Confessions, trans Boulding, Book III, 7(13).

20 'To have the quality of law in what is so commanded the will must be ruled by some reason and the maxim "the prince's will has the force of law" has to be understood with the proviso, otherwise he will make for lawlessness rather than law.' See Aquinas, Summa Theologica, 1a2ae, 90, 2. The text of the Summa is available online at <https://dhspriory.org/thomas/summa/>, accessed 1 June 2018.

21 For a detailed conceptual analysis of Aquinas' treatise on law and its modern-day relevance, see A Lisska, Aquinas's Theory of Natural Law (Oxford, 1996), p 8, in which he attributes renewed interest to developments wherein 'Legal scholars ... began searching for rational justifications of law beyond the theoretical accounts common to legal positivism.' Closer to Aquinas, in ecclesial terms, it is clear that the papal encyclical Aeterni Patris (1879) provided a major impetus for the study of Aquinas. Equally, more recently in the secular forum, the formulation and adoption of international conventions on human rights have inevitably triggered detailed consideration of the rights in question, and of their conceptual origins and justification. As was noted by Lisska (ibid, p 223): 'The Civil Rights Movement initiated a renewed interest in both the existence and the nature of human rights. Since the 1960 s, rights talk has been a central part of much political discussion'. 
was consistent with divine and natural order. ${ }^{22}$ The Aquinian perspective looks beyond the executive power of a sovereign ruler or state constitution as the sole determinant of law and/or the quality of laws. In its place, Aquinas offers a perception of law which is more than a communal imperative or simply the vehicle of social convenience. ${ }^{23}$ In substantive terms, Aquinas makes clear that human laws should bear the hallmark of proportionality. ${ }^{24}$ Proportionality is, of course, here used in a specific, particular, sense, which requires justification by reference to the end to which the law is directed. This is materially different from a general rubric of reasonableness.

In consequence, in engaging with the power of human law (that is, the vinculo iuris), Aquinas reveals a fundamental truth: namely, that it is not possible to classify an ordnance as 'law' without a prior determination of two matters: first, whether the object to which the rule is directed is consistent with the common good; and second, assuming it to be so, whether the specific rule represents a proportionate means of attaining that objective. Any doubt on this matter is removed when regard is had to Aquinas' consideration of the properties of law and the moral response required where the legitimacy of a law is in doubt. As to the former, he addresses the character of law by reference to the object of the rule under scrutiny; the provenance of the rule in question (that is, the competent authority); and the form in which the rule is promulgated. ${ }^{25}$

Aquinas was unequivocal: laws contrary to or inconsistent with the common good could not compel compliance. ${ }^{26}$ However, he emphasised that the evaluation of whether a law was or was not consistent with the common good was not a matter for individual assessment alone. There is no mistaking the fact that these views, expressed as they are in an unparalleled systematic and comprehensive form, were the product not only of personal insight but of Aquinas' harvesting of the labours of others, ${ }^{27}$ Christianising Aristotle as he

Aquinas, Summa, 1azae, 90, 4: 'Natural law is promulgated by God so instilling it into men's minds that they can know it because of what they really are'.

23 For Aquinas, there are three species of law: divine, natural and positive. According to some commentators, Aquinas remains the bridge between natural law theories old and new. See, eg, K Haakonsen, Natural Law and Moral Philosophy (Cambridge, 1996), p 15.

24 Aquinas, Summa, 1azae, 96, 1: 'Whatever is for an end should be proportioned to that end. For law the end should be the common good; Isidore remarks that it should be so composed for no private benefit but for the general welfare of the citizen. Therefore, human law should be proportioned to the common good.'

25 Ibid, 1azae, 96, 4: 'Accordingly laws which apportion in due measure the burdens of responsibility are just, legitimate, and oblige at the bar of conscience.'

26 Ibid, 1azae, 96, 6: 'As already stated, every law is ordained for the common well-being and to that extent gets the force and quality of law; in so far as it falls short it has no binding force' (secundum vero quod ab hoc deficit virtutem obligandi non habet).

27 It has been said that Augustine was every medieval writer's first point of reference: G Evans, Fifty Medieval Thinkers (London, 2002). It is clear that Aquinas would have had access to the writings of Ivo of Chartes (1040-1115) and Peter Lombard (1100-1160), not to mention the impact of Gratian's Decretum (c 1170). 
did so. ${ }^{28}$ On any analysis, Aquinas acknowledged law to be a central component of social order. But, moving from an Aristotelian perspective, he recognised law as fulfilling an essential role in the preservation of the common good and, by that means, the attainment of virtue. Law so viewed is therefore at the service of the community of persons, not its domination.

\section{A POTENTIAL FOR CONFLICT OR COLLABORATION}

With regard to meaning, it is clear that 'law' comprises that set of norms which have (through declaration, determination or custom) been adopted by, or applied to, a given community as the pronouncement of its own identity and commitment to certain societal values or collective ambitions. As Hervada has noted:

These differences in the very notion of law are not to be surprising, since one's notion of law depends on one's notion of the human person and of society. Our society has become so pluralistic that we make people call into question even these most basic ideas. ${ }^{29}$

The Code of Canon Law of the (Latin) Catholic Church (CIC) makes express reference to both rights (ius) and their vindication by means of trial or other process (for example, Canon $1400 \llbracket 1$ ). Further, Canon $1733 \llbracket 1$ provides:

Whenever a person considers himself or herself to be aggrieved by a decree, it is particularly desirable that the person and the author of the decree avoid any contention and take care to seek an equitable solution by common counsel, possibly using the mediation and effort of wise persons to avoid or settle the controversy in a suitable way ...

These should be read as consonant with Canons 22 and 1290, which advocate reliance upon the civil laws where to do so is consistent with the mission of the Church and is not contrary to divine law.

\section{WHAT OF EUROPEAN CONVENTION RIGHTS?}

It may be thought that the theological or doctrinal content of religious laws place them in opposition to the secular legal system. This is an oversimplification. While the self-evident truths recited within the US Declaration of Independence may now find expression in more secular form, we continue to

29 J Hervada, What is Law? The modern response to juridical realism (Montreal, 2009), p 170. 
be presented with international conventions and declarations which profess (in clear and unambiguous terms) the communal ambition which finds distillation in the concept of the 'democratic society'. For present purposes, the European Convention on Human Rights (ECHR) may be considered illustrative. Taken in short form, the Convention affirms the following:

i. The right of autonomy and self-determination of faith communities; ${ }^{30}$

ii. Freedom of thought, conscience and religion of believers and nonbelievers alike; ${ }^{31}$

iii. The right of access to the courts for the vindication of rights; ${ }^{32}$ and

iv. Freedom from discrimination.

\section{Present co-ordinates}

Many will be familiar with the jurisprudence which has evolved around these 'fundamental freedoms' and the conceptual tug of war between the abstract principle and the role of the margin of appreciation. Such matters are outside the scope of this article. For present purposes, it is sufficient to cite the observations of Singh LJ in Adath Yisroel Burial Society $v$ HM Senior Coroner for Inner North London [2018] EWHC 969 (Admin) at paras 114-115:

The principle of equality is one of the most fundamental in a democratic society and is certainly one of the most cherished rights in the Convention and the HRA [Human Rights Act]. As Baroness Hale of Richmond put it in Ghaidan v Godin-Mendoza [2004] UKHL 30; [2004] 2 AC 557, at para. 132: 'Democracy values everyone equally even if the majority does not.'

The kind of society which is envisaged by the Convention and the HRA is one which is based on respect for everyone's fundamental rights, on an equal basis. As we have seen earlier, it is a society which is characterised by pluralism, tolerance and broad-mindedness. ${ }^{33}$

These observations represent a welcome development, seemingly affirming issues of pluralism inter alia in connection with issues of belief, religion and related cultural practices. But one is obliged to ask: do they stand in isolation? Is the accommodation more apparent than real? Two decisions of the senior courts may shed some light on these and related questions.

30 Eg Church of Scientology Moscow v Russia App no 18147/O2 (ECtHR, 5 April 2007).

31 Although not every act in pursuance of religion or belief will be protected: see Arrowsmith $v$ United Kingdom App no 7050/75 (ECtHR, 12 October 1978).

32 Including against the judgments of the faith community tribunals: eg Pellegrini v Italy App no 30882/ 96 (ECtHR, 20 July 2001).

33 As to the Convention recognition of Article 9 rights as inseparable from the notion of the democratic society, see Kokkinakis v Greece App no 14307/88 (ECtHR, 25 May 1993). 
In $R v$ Secretary of State for Education ex parte Williamson [2005] UKHL 15 at paragraph 22, Lord Nicholls observed:

It is not for the court to embark upon an inquiry into the asserted belief and judge its 'validity' by some objective standard such as the source material upon which the claimant founds his belief or the orthodox teaching of the religion in question or the extent to which the claimant's belief confirms to or differs from the views of others professing the same religion.

The sentiment could not be more clearly expressed: it is not for the courts to invigilate doctrinal disputes or matters of orthodoxy and they will not do so. However, the extract is also susceptible to differing explanations. In the first instance, the observation may simply represent judicial confirmation that it is enough for an individual to profess a belief to merit protection, thereby removing any suggestion that the subjective belief must be capable of verification by others before protection is afforded. The second is somewhat broader, namely that Lord Nicholls was adverting to a recognition that the secular courts are ill-equipped and not competent to adjudicate upon such issues.

The second case is AIv MT [2013] EWHC 100 (Fam). The judgment is significant on two discrete counts. First, the courts have traditionally jealously guarded their supervisory jurisdiction over various forms of family-related arrangements, doing so on public policy grounds. Second, the validity of such arrangements are invariably determined (like marriage recognition) by local laws - in the case of the civil law recognition of marriages, through the lex loci celebrationis. ${ }^{34}$

The judgment concerned the High Court ratification of a consent order proposed by the parties. Both were observant orthodox Jews. Their marriage celebration was conducted civilly in Toronto, followed by a religious ceremony in London. The children of the marriage were born in London. When the marriage fell into difficulties, the response of the mother was to visit a rabbi. Both husband and wife were committed to the resolution of their difficulties and any related orders by means of the Beth Din. They proceeded upon this basis. Baker J observed:

At the start of the hearing on 8 February an agreed order was put before me providing for the dismissal of the proceedings for summary return of the children on the basis of an order reciting the agreement reached by the

34 In this respect, see the interesting case of $H A H v S A A$ [2017] IESC 4O, in which the Supreme Court of Ireland was required to rule upon the validity of a marriage within a foreign jurisdiction for immigration purposes. The lex loci celebrationis permitted polygamy. 
parties as to the process to be followed. In particular, the order recited that the parties were agreeing 'to enter into binding arbitration before Rabbi Geldzehler' and undertaking to 'seek and abide by any determination of the family issues through binding arbitration before the New York Beth Din' and specifically asserting that they 'both shall be bound by any award made in the New York Beth Din'. In addition the draft provided that the parties were giving those (and other) undertakings 'voluntarily and on legal advice that such undertaking shall be fully enforceable in the courts in England and Wales in respect of any application for committal and shall be binding and enforceable upon the parties in the courts of Ontario and worldwide'. ${ }^{35}$

He continued:

At the outset of the hearing, however, I indicated to the parties that I did not consider the terms of the draft order to be lawful. In particular, they flouted the principle that the court's jurisdiction to determine issues arising out of the marriage, or concerning the welfare and upbringing of the children, cannot be ousted by agreement. On the other hand, having regard to the parties' devout religious beliefs and wish to resolve their dispute through the rabbinical court, and acknowledging that it [is] always in the interests of parties to try to resolve disputes by agreement wherever possible, including disputes concerning the future of children and ancillary relief of the breakdown of a marriage, I indicated that the court would in principle be willing to endorse a process of non-binding arbitration. Before doing so, however, I requested further information as to the principles and approach to be adopted by the rabbinical authorities to resolving disputes, in particular as to the care of the children. The matter was then adjourned to later in the week. At that point, further information was supplied to the court, in particular a wider range of English legal authorities, together with written material setting out the principles applied by orthodox rabbinical authorities to the resolution of matrimonial disputes, and a short letter from the New York Beth Din replying to a joint letter from the parties' solicitors outlining the approach which would be followed by Rabbi Geldzehler. ${ }^{36}$

The parties were able to come to terms upon this basis, inviting the court to endorse the proposed settlement. Having done so, Baker J added: 
it was an integral aspect of the process of arbitration that it took place under the auspices of the Beth Din. It was a profound belief held by both parties, and their respective extended families, that the marriage which had been solemnised in accordance with the tenets of their faith should be dissolved within those tenets. As Ms Fried observes in the article cited above, 'interpretation of the Talmud suggests that an obligation to utilize a Jewish forum to adjudicate disputes still exists'. In this case, having been reassured as to the principles which would be applied by the rabbinical authorities, which so far as the children were concerned were akin to the paramountcy principle on which English children's law is based, the court was content to accept and respect the parents' deeply-held wishes, subject to the proviso that the outcome could not be binding without the court's endorsement. It does not, however, necessarily follow that a court would be content in other cases to endorse a proposal that a dispute concerning children should be referred for determination by another religious authority. Each case will turn on its own facts.

Thirdly, at a time when there is much comment about the antagonism between the religious and secular elements of society, it was notable that the court was able not only to accommodate the parties' wish to resolve their dispute by reference to their religious authorities, but also buttress that process at crucial stages. ${ }^{37}$

Any euphoria among practitioners was to be short-lived. Within months of the promulgation of the AI v MT decision, the Supreme Court handed down its judgment in the case of Shergill and Ors $v$ Khaira and Ors [2014] UKSC 33. Insofar as is material, the litigation concerned a dispute between different factions of a Sikh temple. The Court of Appeal had concluded that the issue was not justiciable on account of its religious context. Lord Neuberger (with whom all of the members of the Supreme Court were in agreement) concluded otherwise. On the issue of justiciability, he observed:

This distinction between a religious belief or practice and its civil consequences underlies the way that the English and Scottish courts have always, until recently, approached issues arising out of disputes within a religious community or with a religious basis. In both jurisdictions the courts do not adjudicate on the truth of religious belief $\mathrm{s}$ or on the validity of particular rites. But where a claimant asks the court to enforce private rights and obligations which depend on religious issues, the judge may 
have to determine such religious issues as are capable of objective ascertainment. The court addresses questions of religious belief and practice where its jurisdiction is invoked either to enforce the contractual rights of members of a community against other members or its governing body or to ensure that property held on trust is used for the purposes of the trust. We consider each circumstance in turn.

The law treats unincorporated religious communities as voluntary associations. It views the constitution of a voluntary religious association as a civil contract as it does the contract of association of a secular body: the contract by which members agree to be bound on joining an association sets out the rights and duties of both the members and its governing organs. The courts will not adjudicate on the decisions of an association's governing bodies unless there is a question of infringement of a civil right or interest. An obvious example of such a civil interest is the loss of a remunerated office. But disputes about doctrine or liturgy are nonjusticiable if they do not as a consequence engage civil rights or interests or reviewable questions of public law.

The governing bodies of a religious voluntary association obtain their powers over its members by contract. They must act within the powers conferred by the association's contractual constitution. If a governing body of a religious community were to act ultra vires, for example by seeking a union with another religious body which its constitution did not allow, a member of the community could invoke the jurisdiction of the courts to restrain an unlawful union. See Barker v O'Gorman [1971] Ch 215, which concerned a challenge to a proposed union between the Methodist Church and the Church of England on the ground that the Methodist Conference had no power to vary the doctrinal standards of the former church. It is a case involving a private Act of Parliament (the Methodist Church Union Act 1929) rather than a contract. But the principles of ultra vires are the same. See also Long $v$ Bishop of Cape Town (1863) 4 Searle 162 PC, 176 per Lord Kingsdown.

Similarly, members of a religious association who are dismissed or otherwise subjected to disciplinary procedure may invoke the jurisdiction of the civil courts if the association acts ultra vires or breaches in a fundamental way the rules of fair procedure. The jurisdiction of the courts is not excluded because the cause of the disciplinary procedure is a dispute about theology or ecclesiology. The civil court does not resolve the religious dispute. Nor does it decide the merits of disciplinary action if that action is within the contractual powers of the relevant organ of the association: Dawkins v Antrobus [1879] 17 Ch D 615. Its role is more modest: it keeps the parties to their contract. In McDonald v Burns (1940) SC 376, Lord Justice-Clerk Aitchison stated (at pp 383-384): 
"In what circumstances, then, will the Courts entertain actions arising out of judgments of ecclesiastical bodies: Speaking generally, in either of two situations - (first) where the religious association through its agencies has acted clearly and demonstrably beyond its own constitution, and in a manner calculated to affect the civil rights and patrimonial interests of any of its members, and (secondly) where, although acting within its constitution, the procedure of its judicial or quasi-judicial tribunals has been marked by gross irregularity, such fundamental irregularity as would, in the case of an ordinary civil tribunal, be sufficient to vitiate the proceedings. But a mere irregularity in procedure is not enough. ... In short, the irregularity alleged must not be simply a point of form, or a departure from prescribed regulation, but must go to the honesty and integrity of the proceedings complained of." ${ }^{3}$

Having then adverted to the decision in $R v$ Chief Rabbi ex parte Wachmann [1993] 2 All ER 249, Lord Neuberger continued:

The ratio of the judgment in Wachmann was that the Chief Rabbi's decision that the applicant was not religiously and morally fit to hold office as a rabbi did not raise an issue of public law which was amenable to judicial review. The case is not an authority for a proposition that the legality of such disciplinary proceedings is not justiciable. ${ }^{39}$

\section{PROVISIONAL CONCLUSIONS}

Where does the current state of the law leave us? The observations of Baker J in $A I \vee M T$ provide encouragement to faith communities and their members that their own cultures and beliefs are deserving of recognition and accommodation. The Convention jurisprudence generated in relation to Article 9 ECHR affirms the right of faith communities to recognition, autonomy and self-determination. By contrast, the observations of the Supreme Court ought to leave us in no doubt that relationships incepted in the context of faith communities will be subject to the same exercise of judicial scrutiny and interpretation as secular transactions. How does one reconcile these seemingly conflicting perspectives? Much ink has been spilled in connection with the employment status of ministers and, for that matter, the rights of volunteers and others. Yet, in many of these disputes, the classification of the relationship as contractual in character is merely the first question. The real difficulty arises in identifying the rights and obligations which the putative contract conveys. 
In this respect, it is informative to bear in mind that, following Lord Hoffman's analysis in Investors Compensation Scheme $v$ West Bromwich Building Society [1998] 1 WLR 896, the principal gauge adopted by the court is that of 'legitimate expectation'. Having identified the matrix of fact within which the contract was formulated and the environment in which it was to be discharged, the court will scrutinise the relevant transaction, positing the question 'What was each reasonably entitled to expect from the other; having regard to the manner in which they chose to express themselves?'

As is well known among contract lawyers, the judicial task is the ascertainment of the intention which is it be attributed to the parties. Adopting the value-norm-purpose model, it will be apparent that the majority of faith communities will seek to promulgate in written form the values to which it attaches most importance. Obvious examples such as ecclesial discipline, eligibility for ordained ministry and episcopal authority spring to mind. The articulation of these values in the form of legal norms provides clarity. The purpose to which such norms are directed is likely to be rooted in theology and ecclesiology (for example, the duty to proclaim the gospel, or the preservation of the doctrinal orthodoxy and integrity of the faith community itself).

When consideration is given to matters such as these, one might echo the sentiment of the Catholic canonist Ladislas Örsy when he observed that theology is to canon law what botany is to horticulture. Unless faith communities show themselves effective in articulating those values upon which their mission and purpose rests, there is a very real risk that the essential character of their identity will be lost in translation. Now that the lines of justiciability have been re-drawn, the following practical measures ought to be adopted if the integrity of faith communities is to be preserved:

i. Those tasked with advising faith communities are now required to look again at the manner in which relationships within the particular community are classified, documented and evidenced;

ii. Within this revisionary process, first consideration must be given to the rights of autonomy and self-determination enjoyed by the faith community itself;

iii. Ambiguities around the inception, character and termination of relationships (ministerial or otherwise) must be repaired;

iv. Issues of membership and dispute resolution must now be revisited, re-evaluated and assessed in a manner which gives effect to the community's own ecclesiology, doctrine and mission;

v. Contractual arrangements should now make express provision for the resolution of disputes by means of mediation, arbitration or other forms of ADR; and 
vi. While in the field of employment law there are clear statutory prohibitions against contracting out and the like, every effort should be made to ensure that there is a unity between the theological self-understanding advanced by the faith community and the declarations it pronounces.

Experience has shown that exercises of this kind have a tendency to reveal not only areas of material inconsistency but also significant errors of past practice which have been repeated and adopted upon the basis of assumption. Given the implementation of the General Data Protection Regulation, an audit of the type suggested is likely to produce multiple benefits. In the process, we do well to call to mind the fact that what are under consideration here are not the homespun rules of a sporting association but invariably the most profound principles upon which a faith community rests. De minimis non curat lex indeed. 